\title{
Cambios tecnológicos en el contexto publicitario: Dinámicas y tendencias en investigación Presentación
}

\section{Technological changes in the advertising context: Dynamics and trends in Research}

\section{A presentation}

Coordinadoras del número:

Anna Amorós Pons

Profesora Titular de Comunicación Audiovisual y Publicidad

Facultad de Ciencias Sociales y de la Comunicación (Universidad de Vigo) amoros@uvigo.es

\section{Aurora García González}

Profesora Titular de Periodismo (acreditada a Catedrática)

Facultad de Ciencias Sociales y de la Comunicación (Universidad de Vigo)

auroragg@uvigo.es

\section{DATOS DEL NÚMERO}

Fecha de publicación: 26 de enero de 2015

Director de la revista: Francisco García García (Catedrático de Comunicación Audiovisual y Publicidad en la UCM)

Coordinadoras del número: Anna Amorós Pons (Profesora Titular de Comunicación Audiovisual y Publicidad, Universidad de Vigo) y Aurora García González (Profesora Titular de Periodismo, Universidad de Vigo)

Para citar este artículo: Amorós Pons, A. y García González, A (2015):

Cambios tecnológicos en el contexto publicitario: Dinámicas y tendencias en investigación. Presentación, Icono 14, volumen (13), pp. 1-8. doi: $10.7195 /$ ri14.v13i1.772 


\section{Presentación}

Los cambios tecnológicos en el ámbito de la Comunicación están condicionando el contexto publicitario actual. La digitalización de la sociedad ha traído consigo grandes cambios en todos los ámbitos, principalmente para la comunicación y muy en particular para la comunicación publicitaria.

La proliferación de canales (locales y universales; generalistas y temáticos; impresos, electrónicos, online, etc.), junto a la multiplicación de los emisores (empresas, corporaciones, ONG, instituciones...) ha conllevado un progresivo $\mathrm{y}$ desenfrenado aumento de los mensajes publicitarios o comunicativos.

En este contexto se produce un cambio sustancial en la forma en que los publicitarios dirigen sus mensajes a los consumidores. Los social media e Internet resultan la evolución natural de las formas de distribución publicitaria $\mathrm{y}$ son potentes herramientas para controlar y cuantificar el gasto en publicidad. Los anunciantes requieren más datos y nuevas métricas; el branding cobra nuevo impulso y se advierte la necesidad de nuevas estrategias y canales online mixtos.

\section{Presentation}

Technological changes in the field of communication are affecting the current advertising context. Digital society has brought great changes in all areas, mainly for communication and particularly for the advertising communication.

The proliferation of channels (local and universal, general and thematic, print, electronic, online, etc.), together with the multiplication of sources of information (companies, corporations, NG0, institutions ...) has involved a progressive increase in advertising or communication messages.

In this context there is an essential change in the way that publicity agents send messages to consumers. Social media and Internet are the natural evolution of the advertising and distribution methods and these tools are powerful tools to control and quantify advertising spending. Advertisers require more data and new metrics, the branding gains new importance and it is warned the need for new strategies and for mixed online channels.

This monographic covers the state of research from different approaches 
El presente monográfico abarca el estado de la investigación desde distintos enfoques (teórico, histórico-social, periodístico, creativo, redes sociales, producción, recepción y públicos) para ofertar una panorámica amplia del estado de la cuestión, a través de distintas líneas de investigación: Teorías de la comunicación en el contexto transmedia; nuevas formas publicitarias, en escenarios cross-media; personal branding y la estrategia de la figura del periodista como marca personal; innovación estratégica $360^{\circ}$ en la producción; diseños creativos para las nuevas plataformas; diseño social y plataformas cooperativas (movimientos sociales); investigación de mercado y públicos (audiencias y consumidores) en el contexto transmedia; estrategias innovadoras de negocio y nuevos modelos; redes sociales como reguladoras de los mass media.

El monográfico recoge contribuciones de especialistas en diferentes áreas de conocimiento que, investigan desde sus respectivas disciplinas el ámbito de la Publicidad y avizoran nuevas tendencias como consecuencia de los cambios introducidos por el impacto de las nuevas tecnologías.

En este contexto, el volumen se abre con la presentación de los principales (theoretical, social-historical, journalistic, creative, social networks, production, business, public reception) to offer a broad overview of the status of the issue, trough different lines of research: Communication Theories in the transmedia context; New ways of advertising in cross-media stages, Personal branding and the figure of the journalist as a personal brand; $360^{\circ}$ Strategic Innovation in production; Creative Designs for new platforms; Social Design and cooperative platforms (social movements); Market research and public (audiences and consumers) in the transmedia context. Innovative Business Strategies and New Models; Social networks as regulators of the mass media.

This monographic collects contributions from experts in different fields of knowledge who usually research the advertising sphere from their respective disciplines and they were able to watch new trends consequence of changes provoked by the impact of new technologies.

In this context, the volume begins with a presentation of the main results of a research project about social branding. It's a contribution of several researchers belonging to CETAC. Media (Communication Sciences and Technol- 
resultados de un proyecto de investigación sobre desarrollo social de marca. Se trata de una contribución de varios investigadores del CETAC. Media (Communication Sciences and Technologies Research Center), de la Universidade de Aveiro en Portugal, con el título Information and Communication in a Networked Infosphere - a Review of Concepts and Application in Social Branding. En él se propone una revisión global del impacto que tienen la información y la comunicación, y sus tecnologías de apoyo, en la transformación de la vida humana, dentro de lo que se considera la actual "infosfera". El trabajo ofrece un marco para contextualizar el poder de los nuevos enfoques sociales sobre el uso de las tecnologías de información y comunicación al fomentar nuevos modelos de trabajo en las organizaciones. Particularmente interesante resulta la discusión sobre algunas de las tendencias de futuro en cuanto al impacto de las llamadas nuevas tecnologías en este concreto ámbito del saber.

En relación con esta percepción de lo virtual y el cambio que se empieza a detectar, está el artículo de una investigación de la Universidad de Vigo que estudia La prensa digital y las redes sociales en la actividad 2.0 de los menores gallegos. En él, se presenta a los niños ogies Research Center) from the University of Aveiro in Portugal, under the title Information and Communication in a Networked Infosphere - a Review of Concepts and Application in Social Branding. This article proposes a global review of the impact that information, communication and its technologies of supporting have in human life, within the context of the current "infosphere". This work offers a guiding to set in a context the power of the new social approaches on the use of information and communication technologies (ICT) promoting new working models in the organisations. It's particularly interesting the discussion on some future trends regarding with the impact of new technologies in this specific field of knowledge.

In relation with this perception of the virtual and the change that begins to detect, there is a research of the University of Vigo that studies Digital press and social networks in the 2.0 activity of the Galician children. Minors have become an important potential public to the networked entertainment market. They are digital native and their natural relationship with new technologies make that their presence in the net is higher than people of other ages. In relation with this, the mass media, 
como público potencial para el mercado de entretenimiento en Internet con una presencia mayor que otros grupos de edad. En esta línea, la prensa digital trata de atraer su atención con estrategias y proyectos educativos para fidelizarlos como lectores e incrementar sus números de usuarios, lo que resulta imprescindible para mejorar su impacto y ser atractivo para los anunciantes. Este artículo profundiza en el concepto de infancia como usuario digital al ofrecer los resultados de una encuesta realizada a niños gallegos entre 11 y 12 años sobre usos de la red, después de comprobar el nivel de penetración de la prensa digital y de las redes sociales en las rutinas de navegación de este tipo de usuarios a partir de una muestra de 2.200 individuos.

El texto que ofrece la investigación de la Universidad de A Coruña con el título A new challenge for advertising on mobile devices: Social TV destaca el estado actual del mercado de la publicidad en España afectada por la crisis económica mundial y la saturación de los medios de comunicación más tradicionales. El proceso de digitalización subsiguiente ha dado lugar a una transformación significativa en las estrategias de publicidad más tradicionales con el objetivo de adaptarse a un nuevo contexto, más interactivo y digital. the digital press specifically, is trying to attract the children attention with educational strategies to turn them in press's readers and in this way increasing its users. However, there are other online services which are not designed to infancy, but they have the minor's favor: an example is the social networks. In this way, this article deepens in the concept of infancy as digital user to analyze the results of a poll which was replied by children of 11/12 years old to check and compare the penetration level of the digital press and social networks in in children's media habits thanks to a sample of 2.200 individuals.

The text which offers the investigation of the University of A Coruña under the title $A$ new challenge for advertising on mobile devices: Social TV shows the current state of the advertising market in Spain that was affected by the global economic crisis and the saturation of the most traditional media. The subsequent digitization process has provoked a significant transformation in the more traditional advertising strategies under the aim of adapting to a new context, more interactive and digital.

On its behalf, the contribution of the research group belonging to the CEU Cardenal Herrera University, A bit 
Por su parte, la aportación del grupo de investigación de la Universidad CEU Cardenal Herrera, Un poco de rock\&love. Recursos creativos empleados por las marcas en la publicidad para móviles, se centra en el ámbito de las nuevas estrategias de comunicación utilizada por las marcas en la Era Digital. En un contexto globalizado de saturación publicitaria, se hace necesaria la búsqueda de nuevas vías creativas para acercarse a los cada vez más exigentes consumidores. Con un estudio de contenido a las campañas del Festival Cannes Lions-2014, en la categoría de móviles sobre todo a través de apps, se identifican los recursos creativos que responden al postulado del rock\&love en la comunicación publicitaria.

A continuación, el artículo Inbound Marketing en LinkedIn para la gestión de marca, investigación realizada en la Universidad Carlos III de Madrid, se centra en las prestaciones que ofrece LinkedIn para fomentar el Inbound Marketing en la gestión de marca. El estudio, realizado con una gran exhaustividad, se adentra en precisar sobre los usos en concreto que permiten las distintas herramientas que se han ido desarrollando, así como determinar los principios sobre los que se asienta la comunicación que se establece a través de of rock\&love. Creative resources used by brands in mobile advertising, focuses on the field of new communication strategies employed by brands in the Digital Age. In the global context of advertising saturation, it would be necessary the searching of new creative ways to be close to consumers, more and more demanding. Thanks to a content study of the Cannes-Lion-2014 Festival campaigns, in the mobile category specially through apps, the article identifies the creative resources which correspond with the postulate 'rock\&love' in the advertising communication.

Then, the article Inbound Marketing in LinkedIn for the brand management it's a research developed in the University Carlos III of Madrid that focuses on provisions that offers LinkedIn to encourage the Inbound Marketing in the brand management. This study, which was done with thoroughness, explores the specific uses of different tools that have gone developing, as well as determines the principles on which assent the communication through this social network to get attention creating value, with the objective of building loyalty of users who will turn in prescribers at the same time.

The contribution of Networks and so- 
dicha red social para conseguir la atención mediante la creación de valor, con el objetivo de fidelizar a los usuarios y que a su vez estos se conviertan en prescriptores.

La contribución sobre Las redes y los movimientos sociales ¿una acción colectiva o marketing viral?, de la Universidad de Murcia, nos introduce en los movimientos sociales de los últimos años y el papel que estos desempeñan en la sociedad actual, sumergida en las TIC y con los nuevos horizontes que se vislumbran en la comunicación web 2.0. Un estudio centrado en la estructura del marketing para los movimientos sociales y su puesta en marcha.

Finalmente, cerramos este monográfico con la presentación de una investigación reciente realizada en la Universidad de Vigo, Estrategia de comunicación para la inserción laboral en Facebook. Grupos de empleo. Se trata del estudio de Facebook como herramienta para la inserción laboral, donde se parte de la premisa de que los grupos vinculados al ámbito del empleo creados en esta red social pueden ser entendidos como una plataforma cooperativa.

Bajo el enunciado Cambios tecnológicos en el contexto publicitario: Dinámicas cial movements, ¿is it a collective action or viral marketing?, realised at the University of Murcia, enters us in the last years' social movements and their role performance in today's society that is immersed in the ICT with the forecast that offers the 2.0 web communication. Definitely, it's a study focusing on the marketing structure for social movements and their start-up.

Finally, we close this monographic with the presentation of a recent research done in the University of Vigo, Communication strategy for job placement trough Facebook. Employment groups. It's a study that considers Facebook as a tool for the job placement under the assumption that groups created depending on the type of employment in this social network could be as a collaborative platform.

Under the statement Technological changes in the advertising context: Dynamics and trends in Research, the ICONO 14 magazine presents this monographic in which a large group of researchers from different national and international academic centers collaborated with their contributions to exchange perspectives and therefore, enriching the scientific knowledge in Communication sciences field, special- 
8 Anna Amorós Pons y Aurora García González

y tendencias en investigación la revista ICONO 14 presenta este monográfico, donde colaboran un nutrido grupo de investigadores de distintos centros académicos nacionales e internacionales que con sus aportaciones contribuyen al intercambio de perspectivas y así, paulatinamente, ir enriqueciendo el conocimiento científico en el ámbito de las ciencias de la comunicación y, muy particularmente, en la comunicación publicitaria en la Era Digital.

\section{Descriptores}

Publicidad / Teorías / Personal branding / Estrategia $360^{\circ}$ / Diseño creativo/ Plataformas cooperativas / Redes sociales / Transmedia / Crossmedia / Mercados / Público ly, in the advertising communication in the Digital Age context.

\section{Descriptors}

Advertising / Theories / Personal branding / $360^{\circ}$ Strategy / Creative Design / Cooperative Platforms / Social Networking / Transmedia / Crossmedia / Markets / Public

ICONO14 | Año 2015 Volumen 13 NN$^{\circ} 1$ | ISSN: 1697-8293 | DOI: ri14.v13i1.772 